\title{
Online hemodiafilteration use in children: a single center experience with a twist
}

\author{
Magid A. A. Ibrahim', Ihab Z. ElHakim', Dina Soliman², Muhammad A. Mubarak and Ragia M. Said ${ }^{1 *}$
}

\begin{abstract}
Background: Haemodiafilteration (HDF) is a promising new modality of renal replacement therapy (RRT). It is an improvement in the quality of hemodialysis (HD) and thus in the quality of patients'ives. The main obstacle to using HDF is the cost, especially in developing countries. The purpose of this study was to evaluate the benefits of incorporating HDF with different regimens in the treatment of children with end stage renal disease (ESRD).

Methods: Thirty-four children with ESRD on regular HD in Pediatric Dialysis Unit, Children's Hospital, Ain Shams University were followed up in 2 phases: initial phase (all patients: HD thrice weekly for 3 months) and second phase, patients were randomized into 2 groups, HDF group and HD group, the former was subdivided into once and twice weekly HDF subgroups. Evaluation using history, clinical and laboratory parameters at 0, 3, 9 and 18 months was carried out.
\end{abstract}

Results: On short term, we found that the HDF group was significantly superior to HD group regarding all clinical and laboratory parameters. Also, twice HDF subgroup was significantly superior to once HDF subgroup. This was confirmed on long term follow up, but the once HDF proved comparable to twice subgroup.

Conclusions: Incorporating online hemodiafilteration (OL-HDF) in the RRT of children was beneficial in most of the clinical and laboratory parameters measured. It's not all or non; OL-HDF, even once a week, can improve outcomes of HD without significantly affecting the cost.

Keywords: ESRD, HD, OL-HDF, Kt/N, Children

\section{Background}

Hemodiafiltration (HDF) includes diffusive and convective solute removal by ultrafiltering $20 \%$ or more of the blood volume and maintaining fluid balance by infusing sterile replacement fluid into the patient's blood. In online hemodiafiltration (OL-HDF), replacement fluid is obtained by online filtration of dialysate through a series of bacteria- and endotoxin-retaining filters [1].

HDF expands the spectrum of uremic toxin removal from small-sized solutes to middle-sized and large molecular weight solutes [2].

\footnotetext{
* Correspondence: ragia_marei@med.asu.edu.eg

'Department of Pediatrics, Faculty of Medicine, Ain Shams University, Cairo, Egypt

Full list of author information is available at the end of the article
}

Conservation of residual renal function (RRF) in children with ESRD has many benefits including better growth and nutrition, anemia correction, calcium-phosphorous balance, better control of blood pressure and decreasing cardiovascular risk [3]. HDF, though not the best method for conserving RRF, is a better way of renal replacement therapy compared to conventional HD in the context of decreasing intradialytic events that have negative effects on RRF. OLHDF was associated with a $30 \%$ reduction in all-cause mortality compared with conventional hemodialysis $[4,5]$.

The group of middle molecule, defined by a molecular weight $\geq 500 \mathrm{D}$, is mainly composed of small peptides [6]. Many of these are implied in cardiovascular disease, by causing inflammation, endothelial damage, smooth muscle cell proliferation, activation of coagulation or by interfering with calcium/phosphorus homeostasis $[7,8]$.

(c) The Author(s). 2020 Open Access This article is licensed under a Creative Commons Attribution 4.0 International License, which permits use, sharing, adaptation, distribution and reproduction in any medium or format, as long as you give appropriate credit to the original author(s) and the source, provide a link to the Creative Commons licence, and indicate if changes were made. The images or other third party material in this article are included in the article's Creative Commons licence, unless indicated otherwise in a credit line to the material. If material is not included in the article's Creative Commons licence and your intended use is not permitted by statutory regulation or exceeds the permitted use, you will need to obtain permission directly from the copyright holder. To view a copy of this licence, visit http://creativecommons.org/licenses/by/4.0/ The Creative Commons Public Domain Dedication waiver (http://creativecommons.org/publicdomain/zero/1.0/) applies to the data made available in this article, unless otherwise stated in a credit line to the data. 
Many randomized controlled studies stated that OLHDF showed greater efficiency in removing small solutes and in reducing basal levels of phosphate and parathyroid hormone, $[9,10]$ as well as reducing inflammatory parameters such as CRP and IL-6 and pro-inflammatory CD14 ${ }^{+} \mathrm{CD}_{16}{ }^{+}$cells [11-14].

Mazairac et al., (2013) suggest that HDF, compared to HD, belongs to (higher cost, better health) corner [15]. However, McBrien and Manns (2013) proposed that HDF in fact belongs to (higher cost, no impact on health) area [16].

OL-HDF is not yet used worldwide in children and a small number of reports have been published on the effectiveness and safety of the procedure in children. As such, the clinical experience of OL-HDF is still limited, especially in the developing countries, including Egypt where the high cost of this new modality represents an important obstacle. Hence, our study was conducted to evaluate the benefits of implementing this modality with different regimens that can reduce the cost and provide a substantial benefit.

\section{Study design}

Subjects and sample collection

This study is a prospective comparative study (sequential clinical follow up study) and was conducted on children and adolescents following up in the Pediatric Dialysis Unit, Children's Hospital, Ain Shams University. The study included a total of 34 children, $21(61.8 \%)$ boys and $13(38.2 \%)$ girls, their mean age was $14.7 \pm 3.5$ years, they all had ESRD and were on regular hemodialysis, only 31 completed the study to its end. They fulfilled these Inclusion Criteria:1-On regular hemodialysis for at least 3 months.2-Can achieve actual extracorporeal blood flow rate $\left(\mathrm{Q}_{\mathrm{b}}\right)$ of at least $250 \mathrm{ml}$ per min. Exclusion Criteria included:1-Presence of any underlying rheumatological diseases or conditions that can increase inflammatory markers.2-Receiving immunosuppressive treatment or steroids.

This study lasted for 18 months divided into two phases:

I. Initial phase (3 months): All patients were evaluated by clinical and laboratory parameters initially, kept on conventional HD for 3 months, followed up and evaluated again after completing these 3 months (3 months Evaluation).

II. Second phase (15 months): At the end of the initial phase, patients were randomized into 2 groups and 2 subgroups as follows:

\section{A. HDF group: were sub divided into 2 subgroups}

i. Once weekly HDF subgroup (once subgroup): 10 patients were put on OL-
HDF once weekly (middle dialysis session of the week, the remaining two sessions were conventional HD sessions) using dialysis machines available in the pediatric dialysis unit. One patient was lost from this group at 18 months evaluation because of transplantation.

ii. Twice weekly HDF subgroup (twice subgroup): 12 patients were put on OLHDF twice weekly (first and last dialysis sessions of the week, the remaining 3rd session was conventional $\mathrm{HD}$ ). Two patients were lost from this group at 18 months evaluation because of referral to an adult HD unit.

B. HD group: 12 patients were put on conventional hemodialysis thrice weekly to serve as controls for previous groups; being age and sex matched with them.

After this randomization, they were evaluated again twice as follows:

- Evaluation at 9 months: after 9 months from the beginning of the study to assess short term effects of HDF (9 months evaluation).

- Evaluation at 18 months: after 18 months from the beginning of the study to assess long term effects of HDF (18 months evaluation).

We used the percentage change in the measured parameters to assess the changes that occurred in these parameters' values during the study:

Percent change $=(($ value after-value before $) /$ value before)"100 [17].

To assess the short term changes we used the percentage change between 3 months evaluation and 9 months evaluation (Change 3-9) and to assess the long term changes we used the percentage change between 3 months evaluation and 18 months evaluation (Change 3-18).

\section{Methods}

An informed consent was taken from every patient or his/ her caregiver.

All patients were subjected to.

History taking Eclinical examination including: duration on $\mathrm{HD}$ in years, blood flow rate $\left(\mathrm{Q}_{\mathrm{b}}\right)$, dialysate flow rate $\left(\mathrm{Q}_{\mathrm{d}}\right)$, dialyzer size, dialysis related complications: the intradialytic symptomatic hypotension (ISH) and post dialysis fatigue were systematically recorded and expressed as frequency/month. Drug history especially total Erythropoietin (Epo) dose/ month, Epo dose/ $\mathrm{kg}$, and Epo/Hct ratio. Clinical examination with stress on Anthropometric measures: Weight (Wt) and Height (Ht), both are expressed as Standard Deviation Score (SDS) [18] Blood pressure (BP): Predialysis systolic and 
diastolic BP were measured using electronic blood pressure monitors in our unit and mercury sphygmomanometers at home and recorded at each evaluation and BP percentiles were determined [19].

\section{The laboratory parameters evaluation}

A morning predialysis two venous blood samples $(2 \mathrm{~mL}$ each) were obtained from each participant. The first sample was used for measurement of calcium, phosphorus, parathyroid hormone $(\mathrm{PTH}) . \beta_{2}$ microglobulin $\left(\beta_{2} \mathrm{~m}\right)$, interleukin 6 (IL-6) and hs-CRP by ELISA technique. The second sample was used for performing complete blood picture $(\mathrm{CBC})$. Hemoglobin $(\mathrm{Hb})$ and Hematocrit $(\mathrm{Hct})$ and were evaluated in accordance to age and sex [20] to assess severity and progress of anemia.

Assessment of adequacy of dialysis (Kt/V): using online conductivity monitoring (OCM) by dialysis machine. It was calculated as the sum $\mathrm{Kt} / \mathrm{V}$ of the 3 dialysis sessions of the week and expressed as $\mathrm{Kt} / \mathrm{V} /$ week.

\section{The costs versus benefit calculation:}

a) The costs: we calculated only the current costs in 28 days period at each evaluation and expressed as US $\$ /$ month. They were expressed as follows:

- Dialysis costs: It included the sum of all dialysis sessions costs per 28 days, it included prices of dialyzers, blood lines, substitution fluid lines and diasafe filters.

- Non-dialysis costs: It included the sum of all non-dialysis costs that were feasible to be recorded. It included prices of Erythropoietin Simulating Agents (ESA), Iron therapy, activated vitamin $\mathrm{D}$ and phosphate binders.

- Net costs: It is the sum of the previous two, dialysis costs plus non-dialysis costs.

b) The benefits: we created a "benefit score" in our study depending on the long-term improvement, no change or deterioration in clinical and laboratory parameters. We determined a cut off value of $25 \%$ percent change between 3 months and 18 months evaluations to signify improvement or deterioration. Then we calculated the "Total benefit score" for each patient which is the algebraic sum of benefit score for each of the 8 parameters (ISH frequency, Post-dialysis fatigue frequency, Hemoglobin, Calcium, Phosphorus, PTH, $\left.\beta_{2} \mathrm{~m}, \mathrm{IL}-6\right)$ in each patient.

c) The benefit Category: according to the change of the total benefit score, we categorized our patients into 3 categories:

- Benefit: positive total benefit score.

- No change: total benefit score equals zero.

- Deterioration: negative total benefit score.

Table 1 Comparison between different patients' groups as regards clinical parameters at 3, 9 \& 18 months' evaluation

\begin{tabular}{|c|c|c|c|c|c|c|c|c|c|c|}
\hline \multirow[b]{2}{*}{ Variable } & \multirow[b]{2}{*}{ Group } & \multicolumn{3}{|c|}{3 months } & \multicolumn{3}{|c|}{9 months } & \multicolumn{3}{|c|}{18 months } \\
\hline & & Mean & $\pm \mathrm{SD}$ & $p$ & Mean & $\pm \mathrm{SD}$ & $p$ & Mean & $\pm \mathrm{SD}$ & $p$ \\
\hline \multirow{4}{*}{$\begin{array}{l}\text { Weight } \\
\text { (SDS) }\end{array}$} & HDF & -4.90 & 4.26 & 0.1 & -5.00 & 3.29 & 0.1 & -4.40 & 3.11 & 0.1 \\
\hline & $\mathrm{HD}$ & -7.13 & 3.86 & & -6.92 & 3.92 & & -6.60 & 4.00 & \\
\hline & Once & -4.54 & 3.15 & 0.7 & -4.13 & 2.97 & 0.2 & -3.64 & 2.73 & 0.3 \\
\hline & Twice & -5.23 & 5.22 & & -5.78 & 3.53 & & -5.09 & 3.41 & \\
\hline \multirow{4}{*}{$\begin{array}{l}\text { Height } \\
\text { (SDS) }\end{array}$} & HDF & -4.09 & 2.4 & 0.00 & -4.02 & 2.33 & 0.00 & -3.57 & 2.46 & 0.00 \\
\hline & $\mathrm{HD}$ & -6.07 & 1.64 & & -6.03 & 1.67 & & -5.87 & 1.73 & \\
\hline & Once & -3.57 & 2.05 & 0.4 & -3.63 & 1.79 & 0.5 & -3.04 & 1.99 & 0.3 \\
\hline & Twice & -4.55 & 2.71 & & -4.37 & 2.78 & & -4.04 & 2.84 & \\
\hline \multirow[t]{4}{*}{ Intradialytic hypotension (Freq/month) } & HDF & 2.09 & 0.92 & 0.1 & 1.5 & 0.51 & 0.4 & 1.58 & 0.60 & 0.7 \\
\hline & $\mathrm{HD}$ & 1.58 & 0.66 & & 1.67 & 0.65 & & 1.67 & 0.65 & \\
\hline & Once & 1.9 & 0.87 & 0.4 & 1.5 & 0.5 & 1 & 1.56 & 0.5 & 1 \\
\hline & Twice & 2.25 & 0.96 & & 1.5 & 0.5 & & 1.6 & 0.69 & \\
\hline \multirow[t]{4}{*}{ Postdialysis fatigue (Freq/month) } & HDF & 4.91 & 0.86 & 0.00 & 2.77 & 0.06 & 0.01 & 2.32 & 0.67 & 0.00 \\
\hline & $\mathrm{HD}$ & 3.8 & 0.93 & & 4 & 1.27 & & 3.9 & 0.79 & \\
\hline & Once & 4.6 & 0.96 & 0.1 & 3.5 & 0.97 & 0.00 & 2.2 & 0.4 & 0.6 \\
\hline & Twice & 5.17 & 0.71 & & 2.17 & 0.7 & & 2.4 & 0.84 & \\
\hline
\end{tabular}


d) The cost / benefit ratio: In each patient we calculated the incremental costs (the net costs at 18 months evaluation - the net costs at 3 months evaluation) then we divided it by the total benefit score mentioned above and expressed as EGP/ benefit (recalculated as US\$). This ratio was used to compare between different patients' groups and subgroups to decide which is more cost effective.

Note: when the total benefit score of a patient is negative or equals zero (as in some patients in HD group), this patient was cancelled from statistics of cost benefit ratio.

\section{Dialysis methodology}

OL-HDF was performed using the Fresenius dialysis system (Fresenius Medical Care, Bad Homburg, Germany).
The same dialyzers' configurations, the same surface area of the dialyzers using polysulfone membrane-based dialyzer during OL-HDF and the same blood flow rate and dialysate flow rate $(500 \mathrm{~mL} / \mathrm{min})$ and temperature $\left(36^{\circ} \mathrm{C}\right)$ were used during both conventional $\mathrm{HD}$ and $\mathrm{OL}-\mathrm{HDF}$. Bicarbonate powder cartridges (Fresenius Medical Care) were used with ultrapure water for the preparation of bicarbonate-containing dialysis fluid. The substitution fluid was prepared from the dialysis fluid by one additional step of controlled ultrafiltration, before it was infused post-filter into the blood (post dilution mode). We used the on-line system (Fresenius Medical Care, Bad Homburg, Germany), which is integrated into the dialysis machine and consists of two ultrafilters, an infusate pump module and disposable infusate lines. The infusate was prepared continuously by double-stage ultrafiltration.

Table 2 Comparison between different patients' groups as regards laboratory parameters at 3, 9 \& 18 months evaluation

\begin{tabular}{|c|c|c|c|c|c|c|c|c|c|c|}
\hline \multirow[b]{2}{*}{ Variable } & \multirow[b]{2}{*}{ Group } & \multicolumn{3}{|c|}{3 months } & \multicolumn{3}{|c|}{9 months } & \multicolumn{3}{|c|}{18 months } \\
\hline & & Mean & $\pm \mathrm{SD}$ & $p$ & Mean & $\pm \mathrm{SD}$ & $p$ & Mean & $\pm \mathrm{SD}$ & $p$ \\
\hline \multirow{4}{*}{$\begin{array}{l}\mathbf{H b} \\
(\mathrm{gm} / \mathrm{dl})\end{array}$} & HDF & 10.15 & 1.57 & 0.2 & 10.95 & 1.61 & 0.6 & 11.7 & 1.96 & 0.2 \\
\hline & $\mathrm{HD}$ & 10.9 & 1.9 & & 10.6 & 1.7 & & 10.9 & 1.4 & \\
\hline & Once & 10.5 & 1.7 & 0.2 & 10.8 & 1.8 & 0.7 & 11.8 & 2.3 & 0.7 \\
\hline & Twice & 9.7 & 1.3 & & 11.05 & 1.4 & & 11.5 & 1.7 & \\
\hline \multirow{4}{*}{$\begin{array}{l}\mathrm{Ca} \\
(\mathrm{mg} / \mathrm{dl})\end{array}$} & $\mathrm{HDF}$ & 7.88 & 1.30 & 0.7 & 8.85 & 1.55 & 0.4 & 9.24 & 2.21 & 0.5 \\
\hline & $\mathrm{HD}$ & 8.13 & 2.1 & & 8.3 & 2.28 & & 8.7 & 1.8 & \\
\hline & Once & 8.07 & 1.04 & 0.5 & 9 & 1.5 & 0.6 & 9.7 & 1.8 & 0.1 \\
\hline & Twice & 7.73 & 1.5 & & 8.7 & 1.64 & & 8.8 & 2.5 & \\
\hline \multirow{4}{*}{$\begin{array}{l}\mathbf{P} \\
(\mathrm{mg} / \mathrm{dl})\end{array}$} & $\mathrm{HDF}$ & 7.07 & 2.65 & 0.04 & 6.55 & 1.94 & 0.6 & 6.73 & 1.95 & 0.4 \\
\hline & $\mathrm{HD}$ & 5.55 & 1.3 & & 6.87 & 1.59 & & 6.1 & 2.6 & \\
\hline & Once & 8.4 & 3.2 & 0.01 & 7.4 & 1.45 & 0.05 & 7.4 & 2 & 0.1 \\
\hline & Twice & 5.9 & 1.46 & & 5.8 & 2.05 & & 6.1 & 1.7 & \\
\hline \multirow{4}{*}{$\begin{array}{l}\text { PTH } \\
(\mathrm{pg} / \mathrm{ml})\end{array}$} & $\mathrm{HDF}$ & 444.91 & 323 & 0.1 & 366.5 & 328.8 & 0.3 & 193.6 & 205 & 0.8 \\
\hline & $\mathrm{HD}$ & 322 & 392 & & 319 & 384.6 & & 243 & 346.6 & \\
\hline & Once & 429 & 291.2 & 0.8 & 396.9 & 277.1 & 0.3 & 217.6 & 240.9 & 0.5 \\
\hline & Twice & 457 & 361 & & 341.2 & 376.9 & & 172 & 178 & \\
\hline \multirow{4}{*}{$\begin{array}{l}\beta_{2} \mathrm{~m} \\
(\mu \mathrm{g} / \mathrm{ml})\end{array}$} & $\mathrm{HDF}$ & 8.2 & 1.77 & 0.5 & 6.48 & 2.03 & 0.09 & 5.05 & 1.77 & 0.00 \\
\hline & $\mathrm{HD}$ & 8.7 & 3.2 & & 7.9 & 2.39 & & 7.5 & 1.8 & \\
\hline & Once & 8.8 & 1.59 & 0.1 & 7.35 & 2.02 & 0.06 & 5.9 & 1.9 & 0.03 \\
\hline & Twice & 7.67 & 1.78 & & 5.75 & 1.8 & & 4.2 & 1.2 & \\
\hline \multirow{4}{*}{$\begin{array}{l}\text { IL-6 } \\
\text { (pg/ml) }\end{array}$} & $\mathrm{HDF}$ & 237.5 & 96.59 & 0.6 & 192.05 & 83.5 & 0.07 & 119.74 & 56.26 & 0.00 \\
\hline & $\mathrm{HD}$ & 222.9 & 90.1 & & 245.8 & 76.74 & & 250 & 92.9 & \\
\hline & Once & 232.5 & 76.4 & 0.8 & 202.5 & 65.03 & 0.6 & 147 & 49 & 0.03 \\
\hline & Twice & 241.6 & 113.9 & & 183.3 & 98.5 & & 95 & 52.4 & \\
\hline \multirow{4}{*}{$\begin{array}{l}\text { hs-CRP } \\
(\mu \mathrm{g} / \mathrm{ml})\end{array}$} & $\mathrm{HDF}$ & 14.41 & 8.34 & 0.8 & 8.5 & 6.06 & 0.03 & 4.58 & 5.18 & 0.00 \\
\hline & $\mathrm{HD}$ & 14.8 & 9.2 & & 14.9 & 8.86 & & 14.75 & 9.5 & \\
\hline & Once & 12.8 & 9.7 & 0.4 & 9.7 & 7.37 & 0.6 & 6.1 & 7 & 0.2 \\
\hline & Twice & 15.7 & 7.1 & & 7.5 & 4.8 & & 3.15 & 2.1 & \\
\hline
\end{tabular}


Both filters were subjected to automated membrane integrity tests before dialysis and were replaced after 100 treatments or 12 weeks of use, whichever comes first. The online HDF was performed with an infusion rate of one fifth to quarter the blood flow rate guided by trans-membrane pressure (TMP) maintained below 200.

\section{Diet}

No change in "diet routine" and no "special meal plans" were involved in our study.

\section{Statistical methods}

The results were tabulated, graphically represented and analyzed. A $p$-value of $<0.05$ was considered significant. Standard computer program SPSS (Statistical Package for Social Sciences) for Windows, release 13.0 (SPSS Inc., USA) was used for data entry and analysis [21].

\section{Results}

-Descriptive statistics and comparisons between the initial and 3 months evaluations (in all patients as one

Table 3 Comparison between different patients' groups as regards drugs and costs at 3, 9 \& 18 months' evaluation

\begin{tabular}{|c|c|c|c|c|c|c|c|c|c|c|}
\hline \multirow[b]{2}{*}{ Variable } & \multirow[b]{2}{*}{ Group } & \multicolumn{3}{|l|}{3 months } & \multicolumn{3}{|l|}{9 months } & \multicolumn{3}{|l|}{18 months } \\
\hline & & Mean & $\pm \mathrm{SD}$ & $p$ & Mean & $\pm \mathrm{SD}$ & $p$ & Mean & $\pm \mathrm{SD}$ & $p$ \\
\hline \multirow[t]{4}{*}{$\mathrm{Kt} / \mathrm{V} / \mathrm{wk}$} & $\mathrm{HDF}$ & 4.24 & 0.11 & 0.9 & 4.89 & 0.48 & 0.00 & 4.93 & 0.41 & 0.00 \\
\hline & $\mathrm{HD}$ & 4.25 & 0.13 & & 4.2 & 0.1 & & 4.3 & 0.12 & \\
\hline & Once & 4.2 & 0.1 & 0.2 & 4.4 & 0.25 & 0.00 & 4.6 & 0.2 & 0.00 \\
\hline & Twice & 4.2 & 0.12 & & 5.26 & 0.24 & & 5.3 & 0.3 & \\
\hline \multirow{4}{*}{$\begin{array}{l}\text { Epo dose/kg } \\
(U / \mathrm{kg})\end{array}$} & $\mathrm{HDF}$ & 201.9 & 51.13 & 0.2 & 194.6 & 48.7 & 0.3 & 183.8 & 50.20 & 0.8 \\
\hline & $\mathrm{HD}$ & 180.3 & 53.5 & & 176.3 & 52.2 & & 181.4 & 38.8 & \\
\hline & Once & 213.5 & 63.3 & 0.3 & 205.4 & 58.8 & 0.3 & 197.9 & 58.9 & 0.2 \\
\hline & Twice & 192.2 & 38.4 & & 185.6 & 38.7 & & 171 & 39.6 & \\
\hline \multirow{4}{*}{$\begin{array}{l}(\mathrm{EPO} / \mathrm{kg}) / \mathrm{Hct} \\
\text { Ratio }\end{array}$} & $\mathrm{HDF}$ & 6.6 & 2.15 & 0.4 & 6.32 & 1.97 & 0.9 & 5.35 & 2.05 & 0.2 \\
\hline & $\mathrm{HD}$ & 5.9 & 2.6 & & 5.8 & 2.5 & & 5.6 & 1.3 & \\
\hline & Once & 6.8 & 2.4 & 0.3 & 6.5 & 2.6 & 0.2 & 5.8 & 2.5 & 0.5 \\
\hline & Twice & 6.4 & 1.57 & & 5.5 & 1.39 & & 4.9 & 1.45 & \\
\hline \multirow{4}{*}{$\begin{array}{l}\text { Iron dose } \\
\text { (mg/month) }\end{array}$} & $\mathrm{HDF}$ & 183 & 77.97 & 0.2 & 157.6 & 44.27 & 0.5 & 135.26 & 36.87 & 0.2 \\
\hline & $\mathrm{HD}$ & 165 & 82.4 & & 151.6 & 44 & & 145 & 34.2 & \\
\hline & Once & 198 & 110 & 0.7 & 151 & 33.8 & 0.5 & 140 & 46.6 & 0.8 \\
\hline & Twice & 170.8 & 36 & & 162.5 & 40 & & 131 & 27.2 & \\
\hline \multirow{4}{*}{$\begin{array}{l}\text { Dialysis costs } \\
\text { (EGP/month) } \\
\text { (US\$/month) }\end{array}$} & $\mathrm{HDF}$ & 1570 (209.33) & $4.6(0.613)$ & 0.1 & 2247 (299.6) & $224(29.867)$ & 0.00 & $\begin{array}{l}2239 \\
(298.533)\end{array}$ & $\begin{array}{l}225.8 \\
(30.107)\end{array}$ & 0.00 \\
\hline & $\mathrm{HD}$ & 1567 (208.93) & $3.34(0.445)$ & & 1568 (209.067) & $3.25(0.433)$ & & $\begin{array}{l}1568 \\
(209.067)\end{array}$ & $3.25(0.433)$ & \\
\hline & Once & $1569(209.2)$ & $21.52(2.869)$ & 0.4 & 2007 (267.6) & $2.63(0.35)$ & 0.00 & 2007 (267.6) & $2.63(0.35)$ & 0.00 \\
\hline & Twice & 1571 (209.47) & $4.74(0.632)$ & & 2447 (326.267) & $2.63(0.35)$ & & 2448 (326.4) & $3.49(0.465)$ & \\
\hline \multirow[t]{4}{*}{$\begin{array}{l}\text { Non-Dialysis costs } \\
\text { (EGP/month) (US\$/month) }\end{array}$} & $\mathrm{HDF}$ & $1212(161.6)$ & $\begin{array}{l}184.9 \\
(24.653)\end{array}$ & 0.00 & $1142(152.267)$ & $\begin{array}{l}183.2 \\
(24.427)\end{array}$ & 0.07 & $\begin{array}{l}1103 \\
(147.067)\end{array}$ & 217 (28.933) & 0.6 \\
\hline & $H D$ & $\begin{array}{l}841.7 \\
(112.227)\end{array}$ & $\begin{array}{l}407.9 \\
(54.387)\end{array}$ & & 839 (111.867) & $408(54.4)$ & & $\begin{array}{l}1012 \\
(134.933)\end{array}$ & $194(25.867)$ & \\
\hline & Once & $1162(154.933)$ & $213.9(28.52)$ & 0.3 & $1110(148)$ & $209(27.867)$ & 0.6 & $1086(144.8)$ & $243(32.4)$ & 0.7 \\
\hline & Twice & 1267 (168.933) & $152(20.267)$ & & 1183 (157.733) & 155.7 (20.76) & & 1119 (149.2) & $204(27.2)$ & \\
\hline \multirow[t]{4}{*}{$\begin{array}{l}\text { Net costs/m } \\
\text { (EGP/month) (US\$/month) }\end{array}$} & $\mathrm{HDF}$ & 2782 (370.933) & $186.6(24.88)$ & 0.00 & 3389 (451.867) & $\begin{array}{l}302.3 \\
(40.307)\end{array}$ & 0.00 & $\begin{array}{l}3343 \\
(445.733)\end{array}$ & 325 (43.333) & 0.00 \\
\hline & $\mathrm{HD}$ & $2409(321.2)$ & $\begin{array}{l}408.7 \\
(54.493)\end{array}$ & & 2407 (320.933) & 409 (54.533) & & $2580(344)$ & $196(26.133)$ & \\
\hline & Once & $2732(364.267)$ & $216(28.8)$ & 0.3 & $\begin{array}{l}3118.4 \\
(415.787)\end{array}$ & $210(28)$ & 0.00 & $\begin{array}{l}3094 \\
(412.533)\end{array}$ & $243(32.4)$ & 0.00 \\
\hline & Twice & $2839(378.533)$ & 154 20.533) & & 3631 (484.133) & $157.2(20.96)$ & & 3567 (475.6) & $\begin{array}{l}203.8 \\
(27.173)\end{array}$ & \\
\hline
\end{tabular}


group) as regards clinical parameters, laboratory parameters and drugs $\&$ costs revealed that the weight SDS was significantly higher at 3 months evaluation than initial one $(p<0.05)$ and the Epo dose/kg was significantly lower at 3 months evaluation than initial one $(p<$ $0.05)$, no other significant difference was observed between the two evaluations in other parameters,

- Descriptive statistics and comparisons of HDF group versus HD group and once subgroup versus twice subgroup, at 3 months evaluation, 9 months evaluation, and 18 months evaluation are shown in Tables 1, 2, 3 \& Figs. 1, 2. Height SDS was significantly higher in HDF group compared to HD at 3, 9 and 18 months. $\beta 2 \mathrm{~m}$ and IL- 6 were significantly lower in HDF group and in twice HDF group at 18 months while hs-CRP was significantly lower in HDF group at 9 and 18 months. Kt/V/week was significantly higher in HDF group and in twice HDF group at 9 and 18 months.

-Percentage change between 3 months and 9 months evaluations (short term effects) and between 3 months and 18 months evaluations (long term effects) regarding different parameters are shown in Tables 4, 5, 6, Figs. 3, 4.

-Comparisons between different patients' groups as regards the benefit score and cost benefit ratio are shown in Table 7, 8, Fig. 5. All patients on HDF have a positive total benefit score in contrast to patients on HD who have only $33 \%$ with positive total benefit score.

\section{Discussion}

The present study was a sequential (2 phases) clinical follow up study and was aiming at evaluation of the benefits versus costs of substitution of once or twice weekly HD sessions with OL-HDF ones. The purpose of the initial phase was to exclude the occurrence of spontaneous improvement in the studied patient groups before introducing the OL-HDF sessions.

The study showed that the substitution of HD sessions with OL-HDF sessions improved growth compared to pure HD sessions. This is demonstrated by the percent change of weight and height SDS which were significantly higher in HDF group than the HD group, both on short term and long term. Furthermore, once weekly HDF subgroup and twice subgroup had equivalent effect on growth (weight and height), as there was no statistically significant difference between them on either short term and long term evaluation. The improvement in growth which occurred in the present study could be explained by the better dialysis adequacy, clearance of middle molecules and correction of chronic inflammatory state.

Fischbach et al., (2010) demonstrated that daily OLHDF promotes catch-up growth in children on chronic dialysis [22]. However, children in our study were still stunted compared to normal population (no catch up, SDS for weight for age and height for age in HDF group at the end of the study were -4.4 and -3.5 respectively). That is the difference between our study and their study because they used "daily" schedule while we used a more "economic" approach. The $3 \mathrm{H}$ study is set to address the effect of HDF on growth and cardiovascular system [23]. Molina et al., 2018 compared HDF with high-flux HD. HDF was associated with preservation of muscle mass,

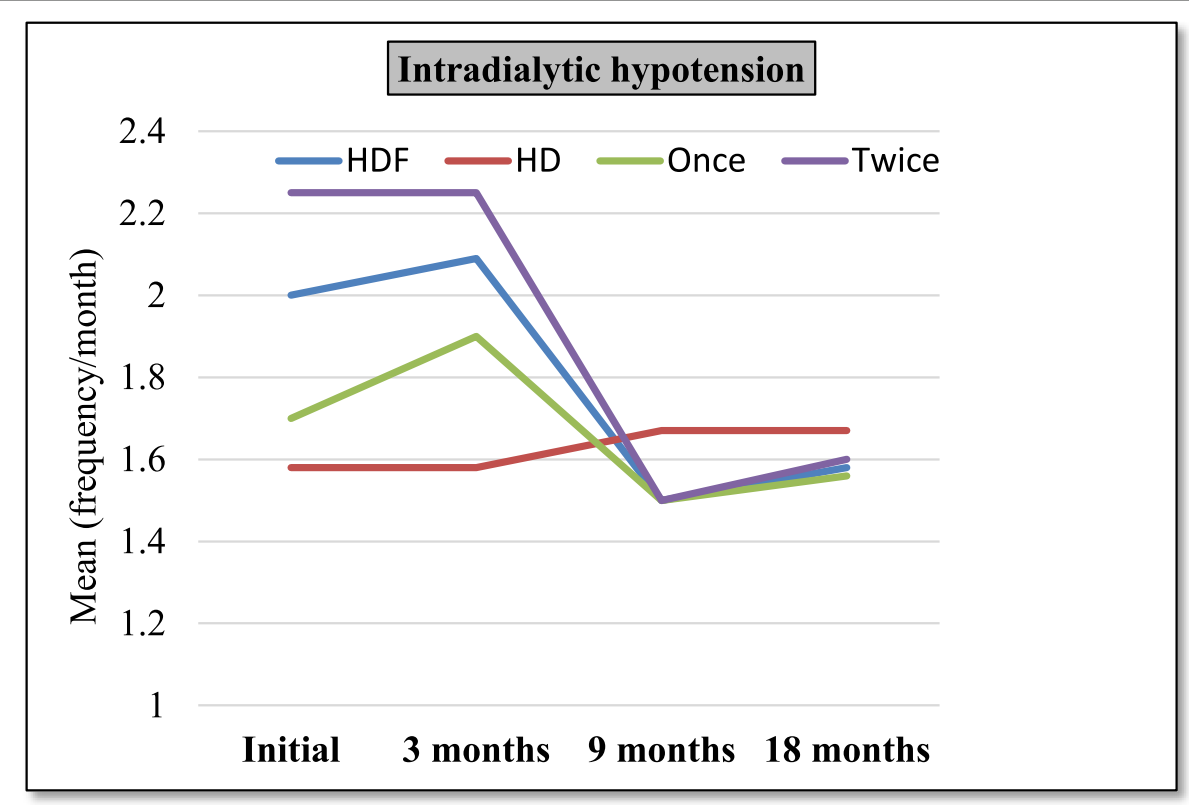

Fig. 1 Line chart for intradialytic hypotension frequency means of different groups 


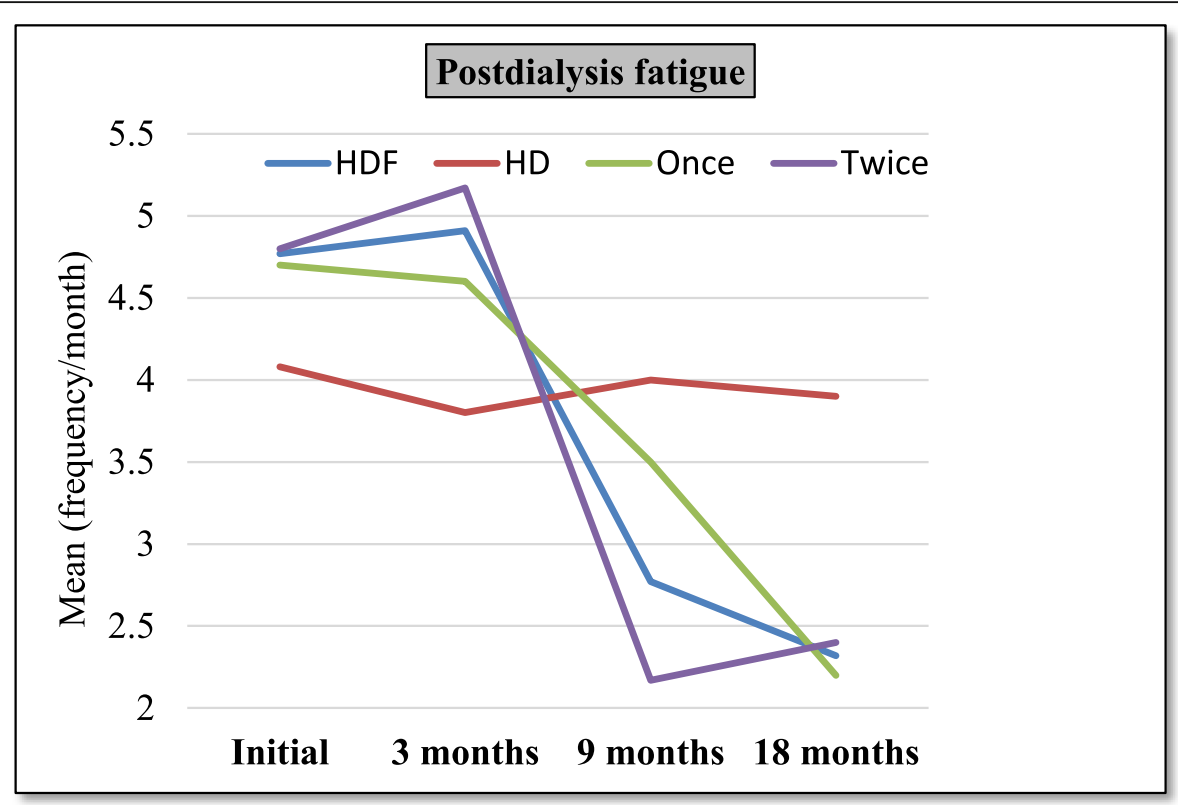

Fig. 2 Line chart for post dialysis fatigue frequency means of different groups

Table 4 Comparison between different groups as regards percentage change in clinical parameters in between 3 months \& 9 months (short term) and 3 months \& 18 months' (long term) evaluations

\begin{tabular}{|c|c|c|c|c|c|c|c|}
\hline \multirow[b]{2}{*}{ Variable } & \multirow[b]{2}{*}{ Group } & \multicolumn{3}{|c|}{$\begin{array}{l}\% \text { change between } \\
3 \text { \& } 9 \text { months } \\
\text { (short term effects) }\end{array}$} & \multicolumn{3}{|c|}{$\begin{array}{l}\% \text { change between } \\
3 \text { \& } 18 \text { months } \\
\text { (long term effects) }\end{array}$} \\
\hline & & Mean & $\pm \mathrm{SD}$ & $p$ & Mean & $\pm \mathrm{SD}$ & $p$ \\
\hline \multirow{4}{*}{$\begin{array}{l}\text { Weight } \\
\text { (SDS) }\end{array}$} & $\mathrm{HDF}$ & -9.48 & 7.07 & 0.01 & -23.10 & 13.50 & 0.00 \\
\hline & $\mathrm{HD}$ & -4.35 & 4.08 & & -10.77 & 10.01 & \\
\hline & Once & -10.19 & 7.69 & 0.6 & -24.86 & 16.10 & 0.6 \\
\hline & Twice & -8.84 & 6.83 & & -21.52 & 11.33 & \\
\hline \multirow{4}{*}{$\begin{array}{l}\text { Height } \\
\text { (SDS) }\end{array}$} & $\mathrm{HDF}$ & -10.15 & 17.03 & 0.00 & -23.5 & 26.26 & 0.00 \\
\hline & $\mathrm{HD}$ & -0.87 & 2.21 & & -3.68 & 5.38 & \\
\hline & Once & -5.57 & 6.01 & 0.6 & -20.38 & 17.86 & 0.5 \\
\hline & Twice & -13.97 & 22.12 & & -26.31 & 32.82 & \\
\hline \multirow{4}{*}{$\begin{array}{l}\text { Intradialytic } \\
\text { Hypotension } \\
\text { (Freq/month) }\end{array}$} & $\mathrm{HDF}$ & -19.69 & 33.97 & 0.1 & -7.45 & 56.71 & 0.5 \\
\hline & $\mathrm{HD}$ & 9.09 & 53.93 & & 4.54 & 56.80 & \\
\hline & Once & -10.00 & 43.88 & 0.3 & 1.85 & 60.34 & 0.4 \\
\hline & Twice & -27.77 & 21.71 & & -15.83 & 55.06 & \\
\hline \multirow{4}{*}{$\begin{array}{l}\text { Postdialysis } \\
\text { fatigue (Freq/month) }\end{array}$} & $\mathrm{HDF}$ & -42.95 & 19.98 & 0.00 & -50.43 & 17.84 & 0.00 \\
\hline & $\mathrm{HD}$ & 4.16 & 21.97 & & 6.66 & 28.87 & \\
\hline & Once & -24.66 & 7.31 & 0.00 & -48.51 & 19.22 & 0.8 \\
\hline & Twice & -58.19 & 12.70 & & -52.16 & 17.35 & \\
\hline
\end{tabular}


Table 5 Comparison between different groups as regards percentage change in laboratory parameters in between 3 months \& 9 months (short term) and 3 months \& 18 months'(long term) evaluations

\begin{tabular}{|c|c|c|c|c|c|c|c|}
\hline \multirow[b]{2}{*}{ Variable } & \multirow[b]{2}{*}{ Group } & \multicolumn{3}{|c|}{$\begin{array}{l}\% \text { change between } \\
3 \& 9 \text { months } \\
\text { (short term effects) }\end{array}$} & \multicolumn{3}{|c|}{$\begin{array}{l}\% \text { change between } \\
3 \& 18 \text { months } \\
\text { (long term effects) }\end{array}$} \\
\hline & & Mean & $\pm \mathrm{SD}$ & $p$ & Mean & $\pm \mathrm{SD}$ & $p$ \\
\hline \multirow{4}{*}{$\begin{array}{l}\mathbf{H b} \\
(\mathrm{gm} / \mathrm{dl})\end{array}$} & HDF & 8.76 & 13.53 & 0.00 & 18.70 & 17.90 & 0.02 \\
\hline & $\mathrm{HD}$ & -2.03 & 11.72 & & 2.18 & 19.72 & \\
\hline & Once & 2.70 & 11.09 & 0.01 & 16.36 & 21.74 & 0.6 \\
\hline & Twice & 13.80 & 13.70 & & 20.82 & 14.50 & \\
\hline \multirow{4}{*}{$\begin{array}{l}\mathrm{Ca} \\
(\mathrm{mg} / \mathrm{dl})\end{array}$} & $\mathrm{HDF}$ & 13.00 & 14.32 & 0.1 & 19.99 & 21.00 & 0.2 \\
\hline & $\mathrm{HD}$ & 3.38 & 22.31 & & 9.81 & 21.43 & \\
\hline & Once & 11.95 & 14.67 & 0.7 & 21.85 & 14.09 & 0.7 \\
\hline & Twice & 13.89 & 14.60 & & 18.33 & 26.46 & \\
\hline \multirow{4}{*}{$\begin{array}{l}\mathbf{P} \\
(\mathrm{mg} / \mathrm{dl})\end{array}$} & HDF & -3.05 & 24.13 & 0.00 & -2.25 & 28.12 & 0.3 \\
\hline & $\mathrm{HD}$ & 25.65 & 21.13 & & 8.76 & 30.46 & \\
\hline & Once & -4.90 & 24.50 & 0.7 & -10.69 & 23.51 & 0.2 \\
\hline & Twice & -1.51 & 24.80 & & 5.33 & 30.91 & \\
\hline \multirow{4}{*}{$\begin{array}{l}\text { PTH } \\
(\mathrm{pg} / \mathrm{ml})\end{array}$} & $\mathrm{HDF}$ & -20.19 & 26.57 & 0.04 & -51.97 & 32.97 & 0.00 \\
\hline & $\mathrm{HD}$ & -2.26 & 14.46 & & -10.56 & 29.65 & \\
\hline & Once & -7.69 & 13.23 & 0.03 & -40.13 & 36.42 & 0.1 \\
\hline & Twice & -30.61 & 30.73 & & -62.63 & 27.0 & \\
\hline \multirow{4}{*}{$\begin{array}{l}\beta_{2} \mathrm{~m} \\
(\mu \mathrm{g} / \mathrm{ml})\end{array}$} & HDF & -21.76 & 15.24 & 0.06 & -38.75 & 15.63 & 0.00 \\
\hline & $\mathrm{HD}$ & -5.9 & 25.31 & & -9.55 & 24.87 & \\
\hline & Once & -17.28 & 14.66 & 0.2 & -33.60 & 15.67 & 0.1 \\
\hline & Twice & -25.50 & 15.3 & & -43.39 & 14.82 & \\
\hline \multirow{4}{*}{$\begin{array}{l}\text { IL-6 } \\
(\mathrm{pg} / \mathrm{ml})\end{array}$} & HDF & -19.54 & 14.05 & 0.00 & -46.20 & 20.33 & 0.00 \\
\hline & $\mathrm{HD}$ & 15.17 & 22.62 & & 15.33 & 26.63 & \\
\hline & Once & -12.20 & 8.34 & 0.01 & -32.07 & 13.96 & 0.00 \\
\hline & Twice & -25.66 & 15.17 & & -58.92 & 16.55 & \\
\hline \multirow{4}{*}{$\begin{array}{l}\text { hs-CRP } \\
(\mu \mathrm{g} / \mathrm{ml})\end{array}$} & HDF & -41.05 & 23.72 & 0.00 & -66.93 & 19.60 & 0.00 \\
\hline & $\mathrm{HD}$ & 9.33 & 40.23 & & 2.94 & 28.47 & \\
\hline & Once & -23.16 & 16.00 & 0.00 & -51.87 & 17.25 & 0.00 \\
\hline & Twice & -55.96 & 18.19 & & -80.48 & 8.54 & \\
\hline
\end{tabular}

$\mathrm{Hb}$ Hemoglobin, $\mathrm{Ca}$ Calcium, $P$ Phosphorus, PTH Parathyroid hormone, $\beta_{2} m$ beta 2 microglobulin, IL-6 interleukin-6, hs-CRP highly sensitive C-reactive protein

increased protein intake, and reduced inflammation, suggesting that HDF could help prevent protein-energy wasting and promote growth [24].

In our study, there were no significant differences between different groups as regards blood pressure categories. But there was some improvement in its control reflected by shift of some patients from uncontrolled category to controlled category. Many authors also support the evidence that there is no significant change in blood pressure values between the convective (HF \&OL-HDF) and the diffusive (LFHD) therapies [14, 25-29].

The HDF group showed decreased frequency of intradialytic symptomatic hypotension (ISH) compared to HD group, yet not reaching a significant difference. This is demonstrated by the decrease of percent change in ISH frequency means in HDF group and increase in the HD group. Also, the twice subgroup showed better improvement in ISH frequency with no statistically significant difference compared to once subgroup both on short term and long term. This came in agreement with many studies that showed a lower ISH frequency in patients who were treated with HDF and HF compared to patients who were treated with low-flux HD, [5, 30-35] others disagree [36, 37].

Fatigue is one of the most common symptoms in hemodialysis patients with a prevalence of $65 \%$ [38]. In the present study, the HDF group showed significant decrease in percent change of post-dialysis fatigue frequency compared to HD group (which actually increased in the latter), both on short term and long term. Also twice subgroup showed statistically significant decrease (negative percent change) of frequency of post-dialysis fatigue on short term only. However, this difference became insignificant on long term suggesting that once weekly HDF might have a slower effect. It is common in clinical practice to find that patients with inadequate dialysis suffer fatigue [39]. This comes in agreement with some studies that reported a statistically significant association between $\mathrm{Kt} / \mathrm{V}$ and fatigue [40]. Several factors may be implicated e.g. anemia, malnutrition and chronic inflammation [39]. Cytokines may cause fatigue either through activation of the central nervous system, hypothalamus, pituitary gland, and adrenal glands or by inducing sleep disorders, depression, or anxiety [41]. Moreover a significant association between fatigue and serum IL- 6 has also been demonstrated in HD patients [42].

In this study, the HDF group showed improvement of anemia compared to HD group. This is demonstrated by the significant increase in hemoglobin levels, and decrease in iron dose, Epo dose/kg and Epo / Hct ratio (a marker of erythropoietin resistance). These changes occurred both on short term and long term. Also, twice subgroup demonstrated a significant increase in hemoglobin level on short term only, to become non-significant on long term. This could be due to the assumed slower effect of once weekly HDF and that improvement of anemia occurred with introduction of HDF regardless of the frequency. The pathogenesis of renal anemia is multifactorial; presence of erythropoietin inhibitors, inadequate dialysis and low Kt/ $\mathrm{V}$, hyperparathyroidism [43] and chronic inflammation $[44,45]$. From our results, we suggested that OL-HDF has corrected the above pathogenic factors, also the use of 
Table 6 Comparison between different groups as regards percentage change in drugs and costs in between 3 months \& 9 months (short term) and 3 months \& 18 months' (long term) evaluations

\begin{tabular}{|c|c|c|c|c|c|c|c|}
\hline \multirow[b]{2}{*}{ Variable } & \multirow[b]{2}{*}{ Group } & \multicolumn{3}{|c|}{$\begin{array}{l}\text { \% change between } \\
3 \text { \& } 9 \text { months } \\
\text { (short term effects) }\end{array}$} & \multicolumn{3}{|c|}{$\begin{array}{l}\text { \% change between } \\
3 \& 18 \text { months } \\
\text { (long term effects) }\end{array}$} \\
\hline & & Mean & $\pm \mathrm{SD}$ & $p$ & Mean & $\pm \mathrm{SD}$ & $p$ \\
\hline \multirow[t]{4}{*}{$\mathrm{Kt} / \mathrm{V} / \mathrm{wk}$} & HDF & 15.24 & 11.35 & 0.00 & 16.47 & 10.50 & 0.00 \\
\hline & $H D$ & -0.46 & 4.83 & & 0.51 & 5.13 & \\
\hline & Once & 5.32 & 7.31 & 0.00 & 8.47 & 5.12 & 0.00 \\
\hline & Twice & 23.50 & 6.18 & & 23.66 & 8.70 & \\
\hline \multirow{4}{*}{$\begin{array}{l}\text { Epo dose/kg } \\
(\mathrm{U} / \mathrm{kg})\end{array}$} & HDF & -3.57 & 2.11 & 0.04 & -11.85 & 10.32 & 0.01 \\
\hline & $H D$ & -2.18 & 1.54 & & 6.47 & 26.48 & \\
\hline & Once & -3.58 & 2.18 & 0.9 & -10.83 & 9.15 & 0.8 \\
\hline & Twice & -3.57 & 2.15 & & -12.76 & 11.69 & \\
\hline \multirow[t]{4}{*}{ (EPO/kg) /Hct Ratio } & HDF & -10.42 & 11.42 & 0.03 & -24.14 & 16.50 & 0.00 \\
\hline & $H D$ & 0.36 & 12.79 & & 7.92 & 36.19 & \\
\hline & Once & -6.41 & 11.35 & 0.1 & -20.68 & 20.53 & 0.6 \\
\hline & Twice & -13.75 & 10.81 & & -27.25 & 12.13 & \\
\hline \multirow{4}{*}{$\begin{array}{l}\text { Iron Dose } \\
\text { (mg/month) }\end{array}$} & $\mathrm{HDF}$ & -5.12 & 27.86 & 0.5 & -21.76 & 25.98 & 0.03 \\
\hline & $\mathrm{HD}$ & -0.03 & 30.23 & & -0.97 & 31.62 & \\
\hline & Once & -12.9 & 33.26 & 0.3 & -22.26 & 33.09 & 0.6 \\
\hline & Twice & 1.88 & 21.3 & & -21.30 & 19.41 & \\
\hline \multirow{4}{*}{$\begin{array}{l}\text { Dialysis costs } \\
\text { (EGP/month) } \\
\text { (US\$/month) }\end{array}$} & HDF & $42.5(5.667)$ & $14.27(1.903)$ & 0.00 & $42.58(5.677)$ & $14.29(1.905)$ & 0.00 \\
\hline & $H D$ & $0.02(0.003)$ & $0.25(0.033)$ & & $0.02(0.003)$ & $0.318(0.0424)$ & \\
\hline & Once & $27.92(3.723)$ & $0.29(0.039)$ & 0.00 & $27.93(3.724)$ & $0.391(0.052)$ & 0.00 \\
\hline & Twice & $55.74(7.432)$ & $0.35(0.0467)$ & & $55.77(7.436)$ & $0.54(0.072)$ & \\
\hline \multirow[t]{4}{*}{ Non-Dialysis costs (EGP/month) (US\$/month) } & HDF & $-5.72(-0.763)$ & $0.96(0.128)$ & 0.00 & $-9.65(-1.287)$ & $8.93(1.191)$ & 0.00 \\
\hline & $\mathrm{HD}$ & $-0.56(-0.075)$ & $1.88(0.251)$ & & $93.68(12.491)$ & $198(26.4)$ & \\
\hline & Once & $-4.56(-0.608)$ & $1.84(0.245)$ & 0.00 & $-7.11(-0.948)$ & $7.05(0.94)$ & 0.02 \\
\hline & Twice & $-6.7(-0.893)$ & $1.46(0.195)$ & & $-11.93(-1.591)$ & $10.16(1.355)$ & \\
\hline \multirow[t]{4}{*}{ Net costs/m (EGP/month) (US\$/month) } & HDF & $21.45(2.86)$ & $7.20(0.96)$ & 0.00 & $19.81(2.6410$ & $7.32(0.976)$ & 0.00 \\
\hline & $H D$ & $-0.08(-0.011)$ & $0.70(0.093)$ & & $9.47(1.263)$ & $17.36(2.315)$ & \\
\hline & Once & $14.22(1.896)$ & $1.50(0.2)$ & 0.00 & $13.27(1.769)$ & $2.12(0.283)$ & 0.00 \\
\hline & Twice & $27.96(3.728)$ & $1.53(0.204)$ & & $25.69(3.425)$ & $4.69(0.625)$ & \\
\hline
\end{tabular}

high quality water that can reduce inflammation is thought to share in this correction so the anemia was improved $[46,47]$. This came in agreement with many studies [46-51].

Stefansson et al (2012)found that OL-HDF decreased serum levels of hepcidin (HEP) which is a major pathogenic factor in renal anemia [49]. A recent randomized trial investigating erythropoietin resistance index (ERI) (weekly Epo dose/ kg/ gmHb) in dialysis patients, demonstrated that OL- HDF caused significant reduction of ERI values [47] However, CONTRAST study found no effect on erythropoiesisstimulating agent resistance [52] and a meta-analysis confirmed the finding [53].
The present study showed that OL-HDF - compared to HD- improved serum Ca levels, yet not reaching a significant difference. Some studies demonstrated that HDF decreases serum ionized $\mathrm{Ca}$ by increasing its clearance $[54,55]$. However, our patients were slightly hypocalcemic at the start of the study (mean 7.7-8.1) and we assume that increased serum $\mathrm{Ca}$ was due to the improved nutrition. Moreover, OL-HDF improves response to vitamin $\mathrm{D}$ action, so it increases gastrointestinal $\mathrm{Ca}$ absorption [56].

Our results showed a significant difference in percent change in the predialysis serum $\mathrm{P}$ in between HDF and HD groups, being decreased (negative) in the former and increased (positive) in the latter. This significant 


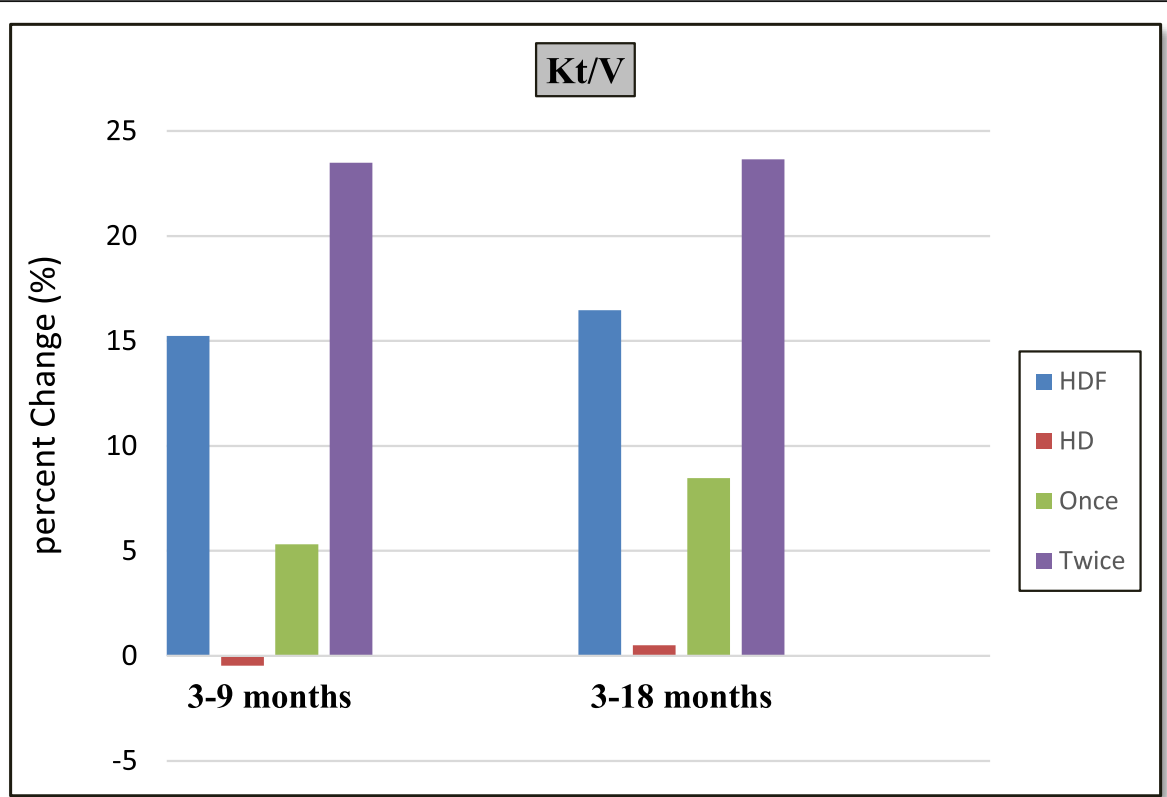

Fig. 3 Column chart for percent changes in $\mathrm{Kt} / \mathrm{N}$ in between different evaluations

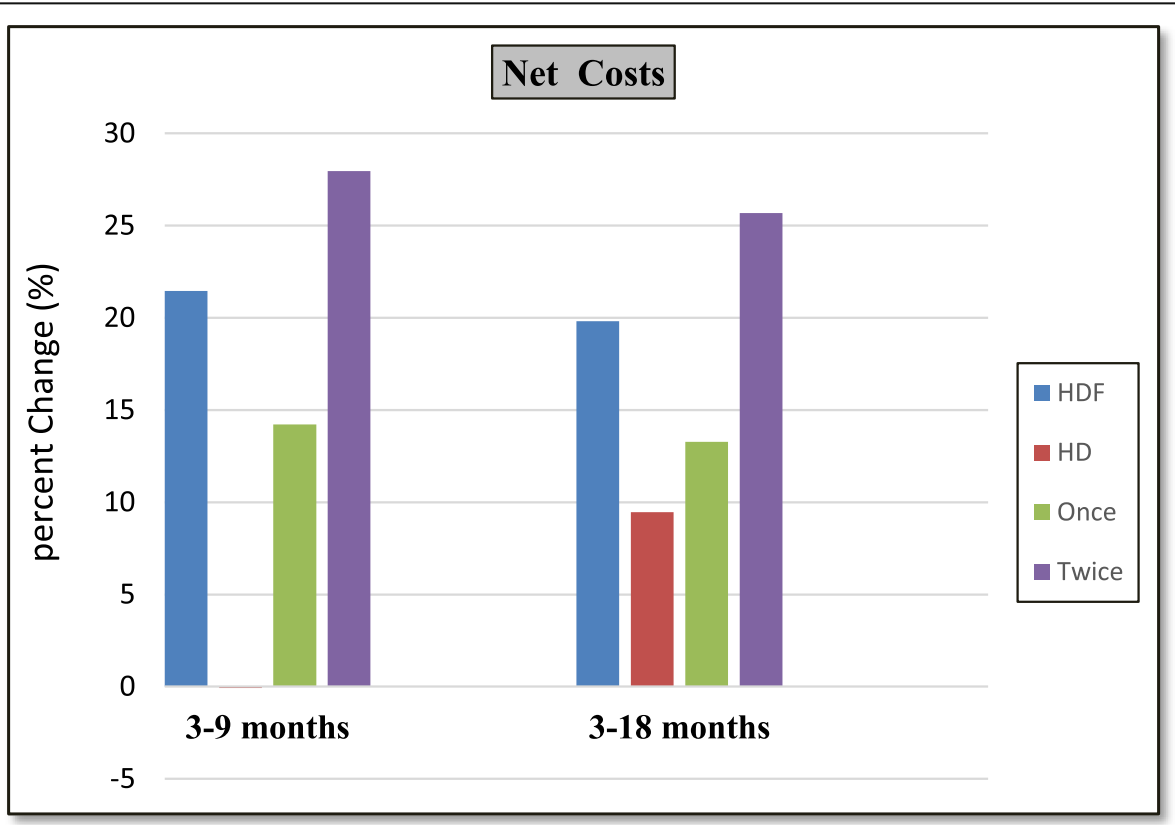

Fig. 4 Column chart for percent changes in net costs in between different evaluations 
Table 7 Comparison between different patients' groups as regards the benefit score category

\begin{tabular}{|c|c|c|c|c|c|c|}
\hline & Benefit Score Cate & & & & $x^{2}$ & $p$ \\
\hline & $\begin{array}{l}\text { Benefit } \\
\text { (+ve total score) }\end{array}$ & $\begin{array}{l}\text { No change } \\
\text { (0 total score) }\end{array}$ & $\begin{array}{l}\text { Deterioration } \\
\text { (-ve total score) }\end{array}$ & $\overline{\text { Total }}$ & & \\
\hline $\mathrm{HDF}$ & $19(100 \%)$ & 0 & 0 & 19 & 17 & 0.00 \\
\hline $\mathrm{HD}$ & $4(33 \%)$ & $2(16.7 \%)$ & $6(50 \%)$ & 12 & & \\
\hline Total & 23 & 2 & 6 & 31 & & \\
\hline Once & $9(100 \%)$ & 0 & 0 & 9 & 0 & 1 \\
\hline Twice & 10 (100\%) & 0 & 0 & 10 & & \\
\hline Total & 19 & 0 & 0 & 19 & & \\
\hline
\end{tabular}

difference was on short term only and became nonsignificant on long term. The phosphorus decrease is due to better clearance by convective force used in HDF $[10,57]$. OL-HDF proved to decrease serum levels of fibroblast growth factor-23(FGF-23) decreasing its harmful effects on calcium phosphate metabolism [58]. Contradictory results were stated by other studies; one study found the amount of phosphate removed with HDF was $15-20 \%$ greater than that with high-flux HD [59], whereas in the second study, no difference was found [60]. Furthermore, in the CONTRAST Study, predialysis serum phosphate levels were reduced by $6 \%$, and the percentage of patients reaching target pretreatment serum phosphorus levels increased from 64 to $74 \%$ [10]., Francisco et al. (2013) stated that OL-HDF was associated with better control of serum phosphorus fraction, compared with hemodialysis [61]. The loss of significance on long term and also the conflicting results of once and twice subgroups could be explained by the fact that serum $\mathrm{P}$ is not dependent only on dialysis modality but it depends more on dietary restriction and compliance to phosphorus binders which may vary and could have affected our results.

In the present study, OL-HDF group showed a significant difference in percent change of PTH levels both on short term and long term. In addition, both once and twice subgroups showed decrease in PTH with significant difference between them on short term but not on long term. In agreement, Wang et al. (2004) proved that HDF clears PTH but HD did not [62]. Movilli et al.

Table 8 Comparison between different patients' groups as regards the cost benefit ratio

\begin{tabular}{llllllll}
\hline Variable & Group & Mean & Median & $\pm S D$ & IQR & Z & $p$ \\
\hline Cost/benefit & HDF & 124.51 & 110.85 & 56.81 & 74 & 1.54 & 0.1 \\
$\begin{array}{l}\text { Ratio } \\
\text { (EGP/benefit) }\end{array}$ & HD & 196.83 & 14 & 372.82 & 566 & & \\
& Once & 96.64 & 78.8 & 38.9 & 37.68 & 2.28 & $\mathbf{0 . 0 2}$ \\
& Twice & 149.59 & 132 & 60.28 & 88.4 & & \\
& Once versus HD & & & & 1.38 & 0.1 \\
& Twice versus HD & & & & 1.4 & 0.1 \\
\hline
\end{tabular}

(2011) demonstrated that after 6 months on OL-HDF, $\mathrm{P}$ and PTH levels significantly decreased compared to the pre HDF levels. This could be explained also by the rise in serum $\mathrm{Ca}$ and the decrease in serum $\mathrm{P}$ mentioned above [63].

The present work proved an enhanced $\beta_{2} \mathrm{~m}$ clearance by HDF where a highly significant decrease in $\beta_{2} \mathrm{~m}$ was revealed on long term only. Furthermore the twice subgroup showed more decrease in predialysis $\beta_{2} \mathrm{~m}$ than once subgroup but not reaching a significant difference. This beneficial effect probably results from use of ultrapure fluids and biocompatible materials reducing inflammation combined with convective therapy that enhances $\beta_{2} \mathrm{~m}$ removal and this is a well-established fact proved in many studies [1, 57, 62, 64-67]. Again, different modalities of implicating HDF proved beneficial.

In ESRD, concentrations of both pro- and antiinflammatory cytokines are several folds higher, probably due to decreased renal clearance and increased production [68]. To assess the effect of HDF on inflammatory state we studied IL- 6 and hs-CRP. Our results revealed that the OL-HDF caused highly significant decrease in both parameters, both on short term and long term. Also the twice group showed a more significant decrease than once group, while the HD group actually showed increase in levels of these parameters. Our results came in agreement with another Egyptian study [69]. Also, many studies demonstrated control of the inflammatory state on OL-HDF $[64,70-72]$. On the contrary, some other studies reported that CRP or IL-6 levels remained stable [11, 57, 73-75]. Moreover, den Hoedt et al. (2014) analyzed data from CONTRAST study and found that HD has increased the levels of IL-6 and CRP while their levels remained stable in patients treated with OLHDF [76].

Our results proved that HDF significantly increased weekly $\mathrm{Kt} / \mathrm{V}$ compared to HD. Also, twice subgroup significantly increased weekly Kt/V compared to once subgroup. This is explained by the higher efficiency of dialysis [47, 63] others don't agree [29, 62].

The HDF group showed significant increase in dialysis costs compared to HD group. Same was found in twice 


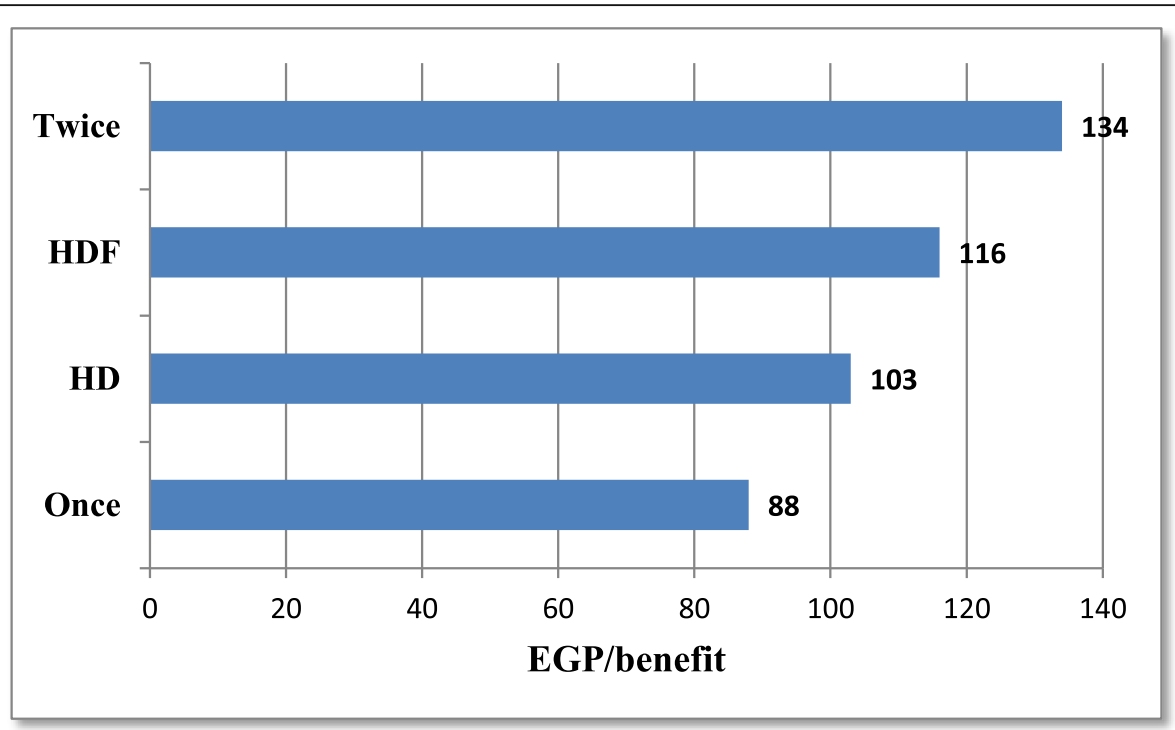

Fig. 5 Bar chart for cost benefit ratio in different groups. To compare cost/benefit ratio between the different groups and subgroups, calculate the incremental costs mean and divide it by the total benefit score mean, as the following: Incremental costs mean /benefit mean in HDF group =554/ $4.78=116$ (EGP/benefit). Incremental costs mean /benefit mean in HD group $=207 / 2=103$ (EGP/benefit). Incremental costs mean /benefit mean in once subgroup $=362.4 / 4.11=88$ (EGP/benefit). Incremental costs mean /benefit mean in twice subgroup $=727.8 / 5.4=134$ (EGP/benefit)

subgroup compared to once subgroup, both on short term and long term. The interesting point in our results is that the non-dialysis costs in HDF group significantly decreased compared to HD group (which actually increased). This is due to the decrease in costs of the drugs (especially, ESAs, phosphate binders and activated Vitamin D). So when we compared the net costs increase between HDF group and HD group at the end of the study, it was found to be statistically insignificant difference.

When studying cost effectiveness of different modes of dialysis in adults, the effect of dialysis is measured by combined measurement of both quantity (survival or mortality rate) and quality of life (QoL) and merging these two parameters into single variable (Quality Adjusted Life or QALY). This can be used statistically to calculate the cost effectiveness as costs/QALY gained [77].

In Egypt, there is no translated questionnaire for assessment of QoL in pediatric ESRD patients and we have no mortality in our study. There is no regional registry collecting data on ESRD and its outcome [78]. Also, we have no defined Society's willing to pay (WTP) in Egypt.

So, in our study, we created the idea of benefit score because we could not calculate the QALY gain. The total benefit score was significantly different between HDF group and HD group. We demonstrated that all HDF group (100\%) had a positive total benefit score while only $33 \%$ of HD group had a positive total score and $50 \%$ of HD patients have a negative total benefit score. The cost/benefit ratio in HDF group was not statistically different from HD group.
We also demonstrated that the once subgroup has the least cost benefit ratio, while the twice subgroup has the highest cost benefit ratio.

Mazairac et al., (2013) performed a detailed cost comparison of HD and HDF in adults on data obtained from CONTRAST study. They found that HDF was slightly more expensive than HD. Although the difference between the two modalities was small, it was not outweighed by the limited QALY gain, so they concluded that HDF is not cost-effective compared to HD [15]. However, another study stated that adequate water treatment and the use of ultrapure dialysate have a favorable cost benefit for dialysis units [79].

The present study, as the first study addressing cost benefit relationship of HDF and HD in children, showed that incremental cost for HDF is acceptable if compared to its clinical and laboratory benefits. The strength of our study comes from the randomized controlled design and the double phase design. Also, to our knowledge, this is the first study to target the cost benefit relationship of HDF and HD in children.

There are some limitations of our study. Firstly, the period of following up the patients on HDF was relatively short (only 15 months). Secondly, the small number of patients included but still it's a reasonable number compared to smaller pediatric ESRD community. Thirdly, not all the costs were documented in details. Lastly, we could not calculate the QALY gain as mentioned above.

In Conclusion The substitution of once or twice weekly HD sessions with OL-HDF sessions was 
beneficial in most of the clinical and laboratory parameters measured. On long term, the twice weekly HDF sessions were statistically better than once in correction of inflammatory profile, elevation of $\mathrm{Kt} / \mathrm{V}$ and more reduction in non-dialysis costs. Otherwise, no statistically significant difference was found between once and twice weekly HDF. The nearly equivalent clinical results in once and twice HDF groups can be due to the limited follow up period. Once weekly HDF had the least cost benefit ratio. So, the way we see it, once weekly HDF is the most cost-effective OL-HDF and may have very promising results in children with ESRD for whom transplantation is not always feasible (such as in our society). The alternative regimens we suggested (once weekly and twice weekly HDF) can represent a breakthrough in renal replacement therapy in children with ESRD in developing countries.

The authors would like to mention that cardiovascular benefit of hemodiafiltration was not tackled in their work neither through measuring plasma indicators such as serum L-carnitine nor through performing echocardiography. Further studies concerning this subject are planned.

\section{Abbreviations \\ HD: Hemodialysis; ESRD: End stage renal disease; HDF: Hemodiafilteration; OL-HDF: Online hemodiafilteration; RRF: Residual renal function; ICER: Incremental cost effectiveness ratio; $\mathrm{Q}_{\mathrm{b}}$ : Blood flow rate; $\mathrm{Q}_{\mathrm{d}}$ : Dialysate flow rate; ISH: Intradialytic symptomatic hypotension; Epo: Erythropoietin; Wt: Weight; Ht: Height; SDS: Standard Deviation Score; Bp: Blood pressure; Ca: Calcium; PO4: Phosphorus; PTH: Parathyroid hormone; $\beta_{2} \mathrm{~m}$ : $\beta_{2}$ microglobulin; FGF-23: Fibroblast growth factor-23; IL-6: Interleukin 6; CRP: C- reactive protein; $\mathrm{CBC}$ : Complete blood count; $\mathrm{Hb}$ : Hemoglobin; HCT: Hematocrit; OCM: Online conductivity monitoring; EGP: Egyptian pound; ESA: Erythropoietin Simulating Agents; TMP: Trans-membrane pressure; hs-CRP: Highly sensitive C- reactive protein; LF-HD: low flux hemodialysis; HEP: Hepcidin; ERI: Erythropoietin resistance index; QoL: Quality of life; QALY: Quality Adjusted Life Year; WTP: Society's willing to pay}

\section{Acknowledgements}

This work was presented as a poster presentation at the 55th ERA EDTA congress, 2018 and an abstract was published in NDT Volume 33, Issue suppl_1, May 2018. https://academic.oup.com/ndt/article/33/suppl_1/11/5001225

\begin{abstract}
Authors' contributions
Prof. M.A.A. I.: supervising the data collection and clinical work. Prof. I. Z. H.: idea of the research and the study design as well as statistical analysis of the collected data. Prof. D. S.: laboratory data. Dr. M. A M.: data collection. Associate Prof. R. M. S.: supervision of data collection and clinical work and manuscript writing. All authors read and approved the final manuscript.
\end{abstract}

\section{Funding}

none.

\section{Availability of data and materials}

All data enrolled in the study are available within their records at our unit. The corresponding author is the one to be contacted in case any data is needed.

\section{Ethics approval and consent to participate}

This study was approved by local ethical committee, Faculty of Medicine, Ain Shams Uninersity. Written consent to participate in the study was obtained from the patient or his/her caregiver.

\section{Consent to publication}

not applicable.

\section{Competing interests}

none.

\section{Author details}

'Department of Pediatrics, Faculty of Medicine, Ain Shams University, Cairo, Egypt. ${ }^{2}$ Department of Clinical Pathology \& Immunology, Faculty of Medicine, Ain Shams University, Cairo, Egypt.

Received: 18 April 2019 Accepted: 15 July 2020

Published online: 28 July 2020

\section{References}

1. Canaud B, Vienken J, Ash S, Ward RA, on behalf of the Kidney Health Initiative HDF Workgroup. Hemodiafiltration to Address Unmet Medical Needs ESKD Patients. Clin J Am Soc Nephrol. 2018;13:1435-43.

2. Canaud B. Online hemodiafiltration. Technical options and best clinical practices. Contrib Nephrol. 2007:158:110-22.

3. Roszkowska-Blaim M, Skrzypczyk P. Residual renal function in children treated with chronic peritoneal dialysis. ScientificWorldJournal. 2013;154537.

4. Canaud B, Bosc JY, Leray-Moragues H, Stec F, Argiles A, Leblanc M, Mion C. On-line haemodiafiltration. Safety and efficacy in long-term clinical practice. Nephrol Dial Transplant. 2000;15(1):60-7.

5. Maduell F, Moreso F, Pons M, Ramos R, Mora-Macia J, Carreras J, Soler J, Torres F, Campistol JM, Martinez-Castelao A, et al. ESHOL study group: highefficiency postdilution online hemodiafiltration reduces all-cause mortality in hemodialysis patients. J Am SocNephrol. 2013;24(3):487-97.

6. Duranton F, Cohen G, De Smet R, Rodriguez M, Jankowski J, Vanholder R, Argiles A. European uremic toxin work G: Normal and pathologic concentrations of uremic toxins. J Am Soc Nephrol. 2012;23(7):1258-70.

7. Neirynck N, Vanholder R, Schepers E, Eloot S, Pletinck A, Glorieux G. An update on uremic toxins. Int Urol Nephrol. 2013;45(1):139-50.

8. Barreto FC, Stinghen AE, de Oliveira RB, Franco AT, Moreno AN, Barreto DV, Pecoits-Filho R, Drueke TB, Massy ZA. The quest for a better understanding of chronic kidney disease complications: an update on uremic toxins. J Bras Nefrol. 2014;36(2):221-35.

9. Pedrini LA, Cristofaro D. V, Comelli M, casino FG, Prencipe M, Baroni a, Campolo G, Manzoni C, coli L, Ruggiero P and others: long-term effects of high-efficiency on-line haemodiafiltration on uraemic toxicity. A multicentre prospective randomized study. Nephrol Dial Transplant. 2011;26(8):2617-24.

10. Penne EL, van der Weerd NC, van den Dorpel MA, Grooteman MP, Levesque R, Nube MJ, Bots ML, Blankestijn PJ, ter Wee PM, Investigators C. Short-term effects of online hemodiafiltration on phosphate control: a result from the randomized controlled convective transport study (CONTRAST). Am J Kidney Dis. 2010;55(1):77-87.

11. Carracedo J, Merino A, Nogueras S, Carretero D, Berdud I, Ramirez R, Tetta C, Rodriguez M, Martin-Malo A, Aljama P. On-line hemodiafiltration reduces the proinflammatory CD14+CD16+ monocyte-derived dendritic cells: a prospective, crossover study. J Am Soc Nephrol. 2006;17(8):2315-21.

12. Filiopoulos V, Hadjiyannakos D, Metaxaki P, Sideris V, Takouli L, Anogiati A, Vlassopoulos D. Inflammation and oxidative stress in patients on hemodiafiltration. Am J Nephrol. 2008;28(6):949-57.

13. Panichi V, Rizza GM, Paoletti S, Bigazzi R, Aloisi M, Barsotti G, Rindi P, Donati G, Antonelli A, Panicucci E, Tripepi G, Tetta C, Palla R, on behalf of the RISCAVID study group. Chronic inflammation and mortality in haemodialysis: effect of different renal replacement therapies. Results from the RISCAVID study. Nephrol Dial Transplant. 2008:23(7):2337-43.

14. Vilar E, Fry AC, Wellsted D, Tattersall JE, Greenwood RN, Farrington K. Longterm outcomes in online hemodiafiltration and high-flux hemodialysis: a comparative analysis. Clin J Am Soc Nephrol. 2009;4(12):1944-53.

15. Mazairac AH, Blankestijn PJ, Grooteman MP, Penne EL, van der Weerd NC, den Hoedt CH, Buskens E, van den Dorpel MA, ter Wee PM, Nube MJ, Bots ML, de Wit GA. The cost-utility of haemodiafiltration versus haemodialysis in the convective transport study. Nephrol Dial Transplant. 2013;28(7):1865-73.

16. McBrien KA, Manns BJ. Haemodiafiltration: not effective or cost-effective compared with haemodialysis. Nephrol Dial Transplant. 2013;28(7):1630-3 discussion 1633

17. Matthews JN, Campbell MJ. Adjusting for baseline: change or percentage change. Stat Med. 1992;11(12):1624-6. 
18. Kuczmarski RJ, Ogden CL, Grummer-Strawn LM, Flegal KM, Guo SS, Wei R, Mei Z, Curtin LR, Roche AF, Johnson CL. CDC growth charts: United States. Adv Data. 2000;314:1-27.

19. National High Blood Pressure Education Program Working Group on High Blood Pressure in C, Adolescents. The fourth report on the diagnosis, evaluation, and treatment of high blood pressure in children and adolescents. Pediatrics. 2004;114(2 Suppl 4th Report):555-76.

20. Hollowell JG, van Assendelft OW, Gunter EW, Lewis BG, Najjar M, Pfeiffer C. Centers for disease C, prevention NCfHS: hematological and iron-related analytes--reference data for persons aged 1 year and over: United States, 1988-94. Vital Health Stat. 2005;11(247):1-156.

21. Daniel WW. Descriptive Statistics. In: Daniel WW, editor. Biostatistics: A foundation for analysis in the health sciences. 9th ed. New York: Wiley; 2009. p. 19-65.

22. Fischbach M, Terzic J, Menouer S, Dheu C, Seuge L, Zalosczic A. Daily on line haemodiafiltration promotes catch-up growth in children on chronic dialysis. Nephrol Dial Transplant. 2010;25(3):867-73.

23. Shroff R, Bayazit A, Stefanidis CJ, Askiti V, Azukaitis K, Canpolat N, Agbas A, Anarat A, Aoun B, Bakkaloglu S, Bhowruth D, Borzych-Dużałka D, Bulut IK, Büscher R, Dempster C, Duzova A, Habbig S, Hayes W, Hegde S, Krid S, Licht C, Litwin M, Mayes M, Mir S, Nemec R, Obrycki L, Paglialonga F, Picca S, Ranchin B, Samaille C, Shenoy M, Sinha M, Smith C, Spasojevic B, Vidal E, Vondrák K, Yilmaz A, Zaloszyc A, Fischbach M, Schaefer F, Schmitt CP. Effect of haemodiafiltration vs conventional haemodialysis on growth and cardiovascular outcomes in children - the HDF, heart and height $(3 \mathrm{H})$ study. BMC Nephrol. 2018;19:199.

24. Molina P. Vizcaı'no B, MolinaMD, Beltra'n S, Gonza'les-MoyaM, Mora a, Castro-Alonso C, Kanter J, a' Vila Al, go' rriz JL, Esta n N, Pallardo' LM, Fouque D, Carrero JJ: the effect of high-volume online haemodiafiltration on nutritional status and body composition: the ProtEin stores prEservaTion (PESET) study. Nephrol Dial Transplant. 2018;7:1223-36.

25. Ward RA, Schmidt B, Hullin J, Hillebrand GF, Samtleben W. A comparison of on-line hemodiafiltration and high-flux hemodialysis: a prospective clinical study. J Am Soc Nephrol. 2000;11(12):2344-50.

26. Beerenhout CH, Luik AJ, Jeuken-Mertens SG, Bekers O, Menheere P, Hover L, Klaassen L, van der Sande FM, Cheriex EC. Meert N and others (2005): predilution on-line haemofiltrationvs low-flux haemodialysis: a randomized prospective study. Nephrol Dial Transplant. 2005;20(6):1155-63.

27. Canaud B, Bragg-Gresham JL, Marshall MR, Desmeules S, Gillespie BW, Depner T, Klassen P, Port FK. Mortality risk for patients receiving hemodiafiltration versus hemodialysis: European results from the DOPPS. Kidney Int. 2006;69(11):2087-93.

28. Orasan RA, Patiu IM, Anghel D, Bejan C, losub L, Totolici C, Pop M, Turcea C, Teodoru C. Orasan $\mathrm{OH}$ and others: variation of clinical and laboratory features in chronic dialysis patients treated with high-flux hemodialysis after switching to online hemodiafiltration. Int Urol Nephrol. 2013;45(5):1415-22.

29. Fadel Fl, Makar SH, Zekri $\mathrm{H}$, Ahmed $\mathrm{DH}$, Aon $\mathrm{AH}$. The effect of on-line hemodiafiltration on improving the cardiovascular function parameters in children on regular dialysis. Saudi J Kidney Dis Transpl. 2015;26(1):39-46.

30. Locatelli F, Altieri P, Andrulli S, Bolasco P, Sau G, Pedrini LA, Basile C, David S, Feriani M, Montagna $G$, et al. Hemofiltration and hemodiafiltration reduce intradialytic hypotension in ESRD. J Am Soc Nephrol. 2010;21(10):1798-807.

31. Mora-Bravo FG, De-La-Cruz G, Rivera S, Ramirez AM, Raimann JG, PerezGrovas $\mathrm{H}$. Association of intradialytic hypotension and convective volume in hemodiafiltration: results from a retrospective cohort study. BMC Nephrol. 2012;13:106

32. Wang AY, Ninomiya T, Al-Kahwa A, Perkovic V, Gallagher MP, Hawley C, Jardine MJ. Effect of hemodiafiltration or hemofiltration compared with hemodialysis on mortality and cardiovascular disease in chronic kidney failure: a systematic review and meta-analysis of randomized trials. Am J Kidney Dis. 2014;63(6):968-78.

33. Tisler A, Akocsi K, Borbas B, Fazakas L, Ferenczi S, Gorogh S, Kulcsar I, Nagy $L$, Samik J, Szegedi J, et al. The effect of frequent or occasional dialysisassociated hypotension on survival of patients on maintenance haemodialysis. Nephrol Dial Transplant. 2003;18(12):2601-5.

34. Shin Jl, Park SJ, Kim JH. Could intradialytic hypotension be due to low baseline magnesium levels or inflammation in hemodialysis patients? Hemodial Int. 2011;15(2):301-2.

35. Morena M, Jaussent A, Chalabi L, Leray-Moragues $H$, Chenine L, Debure A, Thibaudin D, Azzouz L, Patrier L, Maurice F, Nicoud P, Durand C, Seigneuric B, Dupuy AM, Picot MC, Cristol JP, Canaud B, FRENCHIE Study Investigators.
Treatment tolerance and patient-reported outcomes favor online hemodiafiltration compared to high-flux hemodialysis in the elderly. Kidney Int. 2017;91:1495-509.

36. Ok E, Asci G, Toz H, Ok ES, Kircelli F, Yilmaz M, Hur E, Demirci MS, Demirci C, Duman S, Basci A, Adam SM, Isik IO, Zengin M, Suleymanlar G, Yilmaz ME. Ozkahya M; Turkish online Haemodiafiltration study: mortality and cardiovascular events in online haemodiafiltration (OL-HDF) compared with high-flux dialysis: results from the Turkish OL-HDF study. Nephrol Dial Transplant. 2013;28:192-202.

37. Smith JR, Zimmer N, Bell E, Franca BG, McConnachie A, Mactier R. A randomized, single-blind, crossover trial of recovery time in high-flux hemodialysis and hemodiafiltration. Am J Kidney Dis. 2017;69:762-70.

38. Biniaz V, Tayybi A, Nemati E, SadeghiShermeh M, Ebadi A. Different aspects of fatigue experienced by patients receiving maintenance dialysis in hemodialysis units. Nephrourol Mon. 2013;5(4):897-900.

39. Bossola M, Vulpio C, Tazza L: Fatigue in chronic dialysis patients. Semin Dial 2011; 24(5): 550-5.

40. Chang WK, Hung KY, Huang JW, Wu KD, Tsai TJ. Chronic fatigue in longterm peritoneal dialysis patients. Am J Nephrol. 2001;21(6):479-85.

41. Hopkins SJ. Central nervous system recognition of peripheral inflammation: a neural, hormonal collaboration. Acta Biomed. 2007;1(78 Suppl):231-47.

42. Bossola M, Luciani G, Tazza L. Fatigue and its correlates in chronic hemodialysis patients. Blood Purif. 2009;28(3):245-52.

43. Chand DH, Brier M, Strife CF. Comparison of vascular access type in pediatric hemodialysis patients with respect to urea clearance, anemia management, and serum albumin concentration. Am J Kidney Dis. 2005; 45(2):303-8.

44. Adamson JW. Hyporesponsiveness to erythropoiesis stimulating agents in chronic kidney disease: the many faces of inflammation. Adv Chronic Kidney Dis. 2009;16(2):76-82.

45. Kanbay M, Perazella MA, Kasapoglu B, Koroglu M, Covic A. Erythropoiesis stimulatory agent- resistant anemia in dialysis patients: review of causes and management. Blood Purif. 2010;29(1):1-12.

46. Panichi V, Rosati A, Bigazzi R, Paoletti S, Mantuano E, Beati S, Marchetti V, Bernabini G, Grazi G, Rizza GM, Migliori M, Giusti R, Lippi A, Casani A, Barsotti G. Tetta C; RISCAVID study group: Anaemia and resistance to erythropoiesis-stimulating agents as prognostic factors in haemodialysis patients: results from the RISCAVID study. Nephrol Dial Transplant. 2011; 26:2641-8.

47. Panichi V, Scatena A, Rosati A, Giusti R, Ferro G, Malagnino E, Capitanini A, Piluso A, Conti P, Bernabini G, Migliori M, Caiani D, Tetta C, Casani A, Betti G, Pizzarelli F. High-volume online haemodiafiltration improves erythropoiesisstimulating agent (ESA) resistance in comparison with low-flux bicarbonate dialysis: Results of the REDERT study. Nephrol Dial Transplant. 2015;30:682-9.

48. Marcelli D, Bayh I, Merello Jl, Ponce P, Heaton A, Kircelli F, Chazot C, Di Benedetto A, Marelli C, Ladanyi E, Kroczak M, Stuard S, Grassmann A, Scatizzi L, Brand K, Canaud B. Dynamics of the erythropoiesis stimulating agent resistance index in incident hemodiafiltration and high-flux hemodialysis patients. Kidney Int. 2016;90:192-202.

49. Stefansson BV, Abramson M, Nilsson U, Haraldsson B. Hemodiafiltration improves plasma 25-hepcidin levels: a prospective, randomized, blinded, cross-over study comparing hemodialysis and hemodiafiltration. Nephron Extra. 2012;2(1):55-65.

50. Bonforte G, Grillo P, Zerbi S. Surian M (2002): improvement of anemia in hemodialysis patients treated by hemodiafiltration with high-volume online-prepared substitution fluid. Blood Purif. 2002;20(4):357-63.

51. Lin CL, Huang CC, Chang CT, Wu MS, Hung CC, Chien CC. Yang CW (2001 b): clinical improvement by increased frequency of on-line hemodialfiltration. Ren Fail. 2001;23(2):193-206.

52. van der Weerd NC, Den Hoedt CH, Blankestijn PJ, Bots ML, van den Dorpel MA, Le'vesque R, Mazairac AH, Nube' MJ, Penne EL, ter Wee PM, Grooteman MP, CONTRAST Investigators. Resistance to erythropoiesis stimulating agents in patients treated with online hemodiafiltration and ultrapure low-flux hemodialysis: Results from a randomized controlled trial (CONTRAST). PLOS One. 2014;9(4):e94434.

53. Susantitaphong $P$, Siribamrungwong $M$, Jaber BL. Convective therapies versus low-flux hemodialysis for chronic kidney failure: a meta-analysis of randomized controlled trials. Nephrol Dial Transplant. 2013;28:2859-74.

54. Tan HK, Bellomo R, M'Pisi DA. Ronco: ionized serum calcium levels during acute renal failure: intermittent hemodialysis vs. Continuous hemodiafiltration Ren Fail. 2002;24(1):19-27. 
55. Rius A, Hernandez-Jaras J, Pons R, Garcia Perez H, Torregrosa E, Sanchez Canel JJ, Fenollosa MA, Pin MT, Tamarit E. Calvo C (2007): kinetic of calcium, phosphate, magnesium and PTH variations during hemodiafiltration. Nefrologia. 2007;27(5):593-8.

56. Perez-Garcia R, Albalate $M$, de Sequera P, Alcazar R, Puerta M, Ortega M, Corchete E. On-line haemodiafiltration improves response to calcifediol treatment. Nefrologia. 2012;32(4):459-66.

57. Oates T, Pinney JH, Davenport A. Haemodiafiltration versus high-flux haemodialysis: effects on phosphate control and erythropoietin response. Am J Nephrol. 2011;33(1):70-5.

58. Patrier L, Dupuy AM, Granger Vallee A, Chalabi L, Morena M, Canaud B, Cristol JP. FGF-23 removal is improved by on-line high-efficiency hemodiafiltration compared to conventional high flux hemodialysis. J Nephrol. 2013;26(2):342-9.

59. Lornoy W, De Meester J, Becaus I, Billiouw JM, van Malderen PA, van Pottelberge M: Impact of convective flow on phosphorus removal in maintenance hemodialysis patients. J Ren Nutr 2006; 16:47-53.

60. Cornelis T, van der Sande FM, Eloot S, Cardinaels E, Bekers O, Damoiseaux J, Leunissen KM, Kooman JP. Acute hemodynamic response and uremic toxin removal in conventional and extended hemodialysis and hemodiafiltration: a randomized crossover study. Am J Kidney Dis. 2014;64:247-56.

61. Francisco RC, Aloha M, Ramon PS. Effects of high-efficiency postdilution online hemodiafiltration and high-flux hemodialysis on serum phosphorus and cardiac structure and function in patients with end-stage renal disease. Int Urol Nephrol. 2013;45(5):1373-8.

62. Wang C, Lou TQ, Tang H, Chen ZJ, Yin PD, Yu XQ. Clearance effect of different blood purification techniques on parathyroid hormone in renal function failure patients on maintenance hemodialysis. Zhongguo Wei Zhong Bing JiJiu Yi Xue. 2004;16(12):753-5.

63. Movilli E, Camerini C, Gaggia P, Poiatti P, Pola A, Viola BF, Zubani R, Jeannin $G$, Cancarini G. Effect of post-dilutional on-line haemodiafiltration on serum calcium, phosphate and parathyroid hormone concentrations in uraemic patients. Nephrol Dial Transplant. 2011;26(12):4032-7.

64. Ağbaş A, Canpolat N, Calõșkan S, Yõlmaz A, Ekmekci H, Mayes M, Aitkenhead H, Schaefer F, Sever L, Shroff R. Hemodiafiltration is associated with reduced inflammation, oxidative stress and improved endothelial risk profile compared to high-flux hemodialysis in children. PLoS ONE. 2018; 13(6):e0198320.

65. Maduell F. Hemodiafiltration versus conventional hemodialysis: should "conventional" be redefined? Semin Dial. 2018;31:625-32.

66. Panichi V, Manca-Rizza G, Paoletti S, Taccola D, Consani C, Filippi C, Mantuano E, Sidoti A, Grazi G, Antonelli A, et al. Effects on inflammatory and nutritional markers of haemodiafiltration with online regeneration of ultrafiltrate (HFR) vs online haemodiafiltration: a cross-over randomized multicentre trial. Nephrol Dial Transplant. 2006;21(3):756-62.

67. Penne EL, van der Weerd NC, Blankestijn PJ, van den Dorpel MA, Grooteman MP, Nube MJ, Ter Wee PM, Levesque R. Bots ML, investigators $C$ : role of residual kidney function and convective volume on change in beta2-microglobulin levels in hemodiafiltration patients. Clin J Am Soc Nephrol. 2010;5(1):80-6.

68. Carrero JJ, Yilmaz Ml, Lindholm B, Stenvinkel P. Cytokine dysregulation in chronic kidney disease: how can we treat it? Blood Purif. 2008;26(3):291-9.

69. Morad AA, Bazaraa HM, Abdel Aziz RE, Abdel Halim DA, Shoman MG, Saleh ME. Role of online Hemodiafiltration in improvement of inflammatory status in pediatric patients with end-stage renal disease. Iran J Kidney Dis. 2014; 8(6):481-5.

70. Leurs $P$, Lindholm B, Stenvinkel P. Effects of hemodiafiltration on uremic inflammation. Blood Purif. 2013;35(Suppl 1):11-7.

71. Calo LA. Hemodiafiltration and reduction of inflammation in dialysis patients. Kidney Int. 2014;86(3):651.

72. Santoro A, Mancini E. Is hemodiafiltration the technical solution to chronic inflammation affecting hemodialysis patients? Kidney Int. 2014;86(2):235-7.

73. Vaslaki LR, Berta K, Major L, Weber V, Weber C, Wojke R, Passlick-Deetjen J, Falkenhagen D. On-line hemodiafiltration does not induce inflammatory response in end-stage renal disease patients: results from a multicenter cross-over study. Artif Organs. 2005;29(5):406-12.

74. Kuo HL, Chou CY, Liu YL, Yang YF, Huang CC. Lin HH (2008): reduction of pro-inflammatory cytokines through hemodiafiltration. Ren Fail. 2008;30(8): 796-800.

75. Tiranathanagul K, Praditpornsilpa K, Katavetin P, Srisawat N, Townamchai N, Susantitaphong P, Tungsanga K, Eiam-Ong S. On-line hemodiafiltration in
Southeast Asia: a three-year prospective study of a single center. The Apher Dial. 2009;13(1):56-62.

76. den Hoedt $\mathrm{CH}$, Bots ML, Grooteman MP, van der Weerd NC, Mazairac AH, Penne EL, Levesque R, ter Wee PM, Nube MJ, Blankestijn PJ, et al. Online hemodiafiltration reduces systemic inflammation compared to low-flux hemodialysis. Kidney Int. 2014;86(2):423-32.

77. Vecchio MD, Giordana G, Pedrini LA, Marcelli D, Sisti NJ. Elements for economic evaluation on online Hemodiafiltration (Ol-HDF) versus standard Haemodialysis to treat patients with end-stage renal disease (ESRD). IJPH. 2012;9(4):27-37.

78. Youssef DM, Neemat-Allah MA. Hemodialysis in children: eleven years in a single center in Egypt. Iran J Kidney Dis. 2013;7(6):468-74.

79. Upadhyay A, Jaber BL. We use impure water to make dialysate for hemodialysis. Semin Dial. 2016;29:297-9.

\section{Publisher's Note}

Springer Nature remains neutral with regard to jurisdictional claims in published maps and institutional affiliations.
Ready to submit your research? Choose BMC and benefit from:

- fast, convenient online submission

- thorough peer review by experienced researchers in your field

- rapid publication on acceptance

- support for research data, including large and complex data types

- gold Open Access which fosters wider collaboration and increased citations

- maximum visibility for your research: over $100 \mathrm{M}$ website views per year

At BMC, research is always in progress.

Learn more biomedcentral.com/submissions 